\title{
Antioxidant Activity from the Combination of Ethanolic Extract of Tea Leaves (Camellia sinensis) and Soursop Leaves (Annona muricata I.) and Optimation of the Effervescent Granule Production
}

Uji Antioksidan Kombinasi Ekstrak Etanolik Daun Teh (Camellia sinensis) dan Daun Sirsak (Annona muricata I.) dan Optimasi Formulasi Sediaan Granul Effervescent

\author{
Fatma Sari Masitha ${ }^{1}$, Rifki Febriansah ${ }^{1 *}$ \\ 1 Program Studi Farmasi, Fakultas Kedokteran dan IImu Kesehatan, Universitas Muhammadiyah Yogyakarta, Yogyakarta
}

DATA OF ARTICLE:

Received: 21 Feb 2019

Reviewed: 16 Mar 2019

Revised: 21 May 2019

Accepted: 23 Jun 2019

*CORRESPONDENCE:

rifki.febriansah@umy.ac.id

DOI:

10.18196/mm.190230

TYPE OF ARTICLE: Research

\begin{abstract}
Soursop Leaves (Annona muricata L.) and Tea Leaves (Camellia sinensis) are plants that contain flavonoids which are considered to act as antioxidants and can become chemopreventive agents. This study aims to identify the potential of Soursop Leaves and Tea Leaves as chemopreventive agents. The first stage of this research was to determine the presence of flavonoids in both of ethanolic extract using TLC method. The second stage is to examine the antioxidant activity of the combination of ethanolic extract of soursop leaves and tea leaves against free radical DPPH (1,1-diphenyl-2-pikrihidrazil). Docking molecular test of acetogenin and catechin compounds at HER-2 and ER- $\alpha$ receptors which are biomarkers of breast cancer. Furthermore, the optimization of effervescent granule production using moist granulation method is carried out. The result shows that ethanolic extract of soursop leaves and tea leaves contains flavonoid shown with $\mathrm{Rf}$ value of 0.66 and 0.68 , and the comparison of $\operatorname{Rf} 0.66$. The combination of both ethanolic extract has very strong antioxidant activity with $\mathrm{IC}_{50}$ value $26,90 \mu \mathrm{g} / \mathrm{mL}$. The result of molecular docking of acetogenin and catechin compounds at HER-2 receptors shows respective docking score of $-6.3 \mathrm{kcal} / \mathrm{mol}$ and $-6.7 \mathrm{kcal} / \mathrm{mol}$ while ER- $\alpha$ receptors shows a docking score of $-6.5 \mathrm{kcal} / \mathrm{mol}$ and $-7.6 \mathrm{kcal} / \mathrm{mol}$. In addition, the most optimal effervescent granule production is formula four with physical test result such as moisture content of $1.07 \%$ with a dissolve time of 45.5 seconds and acidity of 6.18. The result shows that ethanolic extract of soursop leaf (Annona muricata L.) and Tea Leaves (Camellia sinensis) have potential activity as chemopreventive agents and can be formulated into effervescent granule production.
\end{abstract}

Keywords: Annona muricata; Camellia sinensis; Antioxidant; Effervescent Granule; Molecular Docking

Abstrak: Daun sirsak (Annona muricata L.) dan daun teh (Camellia sinensis) merupa-kan tanaman yang memiliki kandungan senyawa flavonoid yang diduga berperan sebagai antioksidan dan dapat menjadi agen kemopreventif. Penelitiaan ini bertujuan untuk mengetahui potensi dari daun sirsak dan daun teh sebagai agen kemopreventif. Metode penelitian yang digunakan yaitu eksperimental, serbuk daun Sirsak dan daun Teh dimaserasi menggunakan etanol $70 \%$. Identifikasi golongan senyawa ekstrak menggunakan meto-de KLT dengan fase gerak n-Butanol : Asam Asetat : Air (7:2:1). Uji antioksidan dengan metode DPPH (1,1-difenil-2-pikrihidrazil), uji molecular docking senyawa acetogenin dan katekin pada protein reseptor HER-2 dan ER- $\alpha$, dan dilakukan optimasi formula 
sediaan granul effervescent kombinasi ekstrak menggunakan metode granulasi basah. Hasil penelitian menunjukkan bahwa ekstrak etanol daun sirsak dan daun teh mengandung senyawa golongan flavonoid ditunjukkan dengan nilai $R f$ yaitu 0,66 dan 0,68 serta pembanding rutin dengan $R f$ 0,66. Kombinasi ekstrak etanolik daun sirsak dan daun teh memiliki aktivitas antioksidan yang sangat kuat dengan nilai $\mathrm{IC}_{50}$ sebesar 26,9 $\mathrm{kg} / \mathrm{mL}$. Hasil uji molecular docking senyawa acetogenin dan katekin pada reseptor HER-2 menunjukkan docking score secara berurutan -6,3 dan $-6,7 \mathrm{kcal} / \mathrm{mol}$, sedangkan pada reseptor ER- $\alpha$ menunjukkan docking score seca ra berurutan -6,5 dan -7,6 kcal/mol. Sediaan granul effervescent yang paling optimal yaitu formula empat dengan hasil uji fisik berupa kadar air 1,07\% dengan waktu larut 45,5 detik dan keasaman pH 6,18. Hasil uji menunjukkan bahwa ekstrak etanol Daun Sirsak dan Daun Teh berpotensi sebagai agen antioksidan dan dapat diformulasikan menjadi sediaan granul effervescent.

Kata Kunci: Annona muricata L.; Camellia sinensis; Antioksidan; Docking Molekuler; Granul Effervescent

\section{INTRODUCTION}

One of cancers that has the highest incidence rate in Indonesia is breast cancer, the new incidence rate of which reaches up to $43.3 \%$. Breast Cancer is a type of cancer that ranks first in women. It usually attacks women over 50 years of age. In Indonesia, according to the Cancer Registration Agency of Indonesian Pathology Specialist Association and the Indonesian Cancer Foundation (ICF) in 2010, the breast cancer incidence rate in Indonesia is 12 out of 100,000 women, and it has risen steadily since 2002. ${ }^{1}$

Tea leaves (Camellia sinensis) have many benefits, the biggest of which is as a powerful antioxidant as it contains catechin compound. Catechins are believed to be a powerful antioxidant that can suppress cell proliferation and have a chemo preventive effect. Soursop leaves (Annona muricata L.) have also been shown to have anticancer effects. The acetogenin compound has been proven to become anticancer and cytotoxic agents. This study aims to identify the potential antioxidant of a combination of Camellia sinensis and Annona muricata $\mathrm{L}$. leaves and the optimization of its formulation into effervenscent granule production.

\section{MATERIAL AND METHOD}

Plant Identification. The test materials, Camellia sinensis and Annona muricata, were identified before they were used for research. Plant identification was carried out at the laboratory of Faculty of
Biological Pharmacy, Universitas Gadjah Mada, Yogyakarta.

Extraction. The extraction process used maceration method by dissolving simplicia pollen into $70 \%$ ethanol with a ratio of pollen : $70 \%$ ethanol ( 1 : $6)$. The simplicia pollen was soaked into $70 \%$ ethanol for 4 days.

Chemical Compounds Test. This test was carried out by using TLC method. The mobile phase used is such as $n$ - Butanol: Acetic Acid : Water (BAA) with a ratio of $7: 2: 1$ while the stationary phase used is silica gel GF 254 . Upon the elution process, the TLC plate was removed from the chamber and dried in an oven within $60^{\circ} \mathrm{C}$ for 10 minutes. Afterwards, the plate was observed under a UV lights with a wavelength of $254 \mathrm{~nm}$ and the results and its $\mathrm{Rf}$ score were examined. Furthermore, the colour reagent, ammoniac vapor, was used to detect flavonoids.

Antioxidant Activity Test. The DPPH standard solution was made by dissolving $15.8 \mathrm{mg}$ of DPPH powder into a measuring flask. It was then dissolved into $100 \mathrm{~mL}$ of methanol p.a to obtain a concentration of $0.4 \mathrm{mM}$. The solution was vortexed for 30 seconds and wrapped using aluminium foil. Furthermore, vitamin $C$ solution was made by dissolving $5 \mathrm{mg}$ of vitamin $\mathrm{C}$ and was put into a 50 $\mathrm{mL}$ of measuring flask. Methanol was then added up to the limits as the mother liquor. Subsequently, series of vitamin $C$ was graded into 0.5 ; 1 ; 5 ; 10; 20; $30 \mu \mathrm{g} / \mathrm{mL}$. Subsequently, $20 \mathrm{mg}$ of a combination of ethanoic extract of both soursop leaves and tea leaves was dissolved along with $20 \mathrm{~mL}$ of methanol p.a to obtain a concentration of $1000 \mu \mathrm{g} / \mathrm{mL}$. The series of mother liquor from such combination was graded into $5 ; 7.5 ; 10 ; 15 ; 20 ; 30 \mu \mathrm{g} / \mathrm{mL}$. Furthermore, operating time is determined by preparing $35 \mathrm{~mL}$ volumetric flasks, and then fill the three volumetric flasks with $1 \mathrm{~mL}$ of vitamin $\mathrm{C}$ solution with the degree of 3; 4 and $5 \mu \mathrm{g} / \mathrm{mL}$, respectively. Add $1 \mathrm{~mL}$ of DPPH solution into each volumetric flask and add methanol to the limits. Move each solution in the measuring flask into the test tube then Vortex for 30 seconds. Read the absorbance of the solution at $\lambda 514 \mathrm{~nm}$ every 5 minutes for 45 minutes, and do it within 3 -time replication. The maximum wavelength is identified by filling the $10 \mathrm{~mL}$ volumetric flask with $1 \mathrm{~mL}$ of DPPH solution, and adding methanol to the limits. The solution is then moved into a test tube and Vortex the solution for 30 seconds. Leave the solution during operating time and read the absorption at a wavelength of $200-800 \mathrm{~nm}$. Absorbance of DPPH solution was measured by filling $2 \mathrm{~mL}$ of DPPH solution into a $10 \mathrm{~mL}$ volumetric flask. Add methanol to the limits and leave it during operating time. Read absorption at $\lambda$ maximum and do it within 3 -time replication. Furthermore, the absorb- 
ance of vitamin $\mathrm{C}$ solution and samples was measured by filling $2 \mathrm{~mL}$ of DPPH solution into a $10 \mathrm{~mL}$ volumetric flask. Add $2 \mathrm{~mL}$ of vitamin C or sample solution to the series of concentration made and add methanol to the limits. Vortex the solution for 30 seconds, and leave it during operating time. Read absorption at $\lambda$ maximum and do it within 3 -time replication.

Inhibition Concentration $50\left(\mathrm{IC}_{50}\right)$ was calculated by processing sample absorbance data into \% antioxidant with the formula as follows:

$\%$ inhibition $=\frac{\text { Blank absorbance-Sample absorbance }}{\text { Blank absorbance }} \times 100 \%$

Value $\mathrm{IC}_{50}$ can be obtained by entering the value 50 as $y$ in the linear regression equation obtained from the relationship of $x=$ level and $y=\%$ antioxidants.

Molecular Docking. In this research, the data of target protein structure was obtained through Protein Data Bank (GDP) by accessing www. rcsb.org. PDB ID used was HER-2 as the target docking with 3 PPo as protein code and ER-a with code 6BoF. Then download the file with PDB format. The receptor file and ligand test compound with pdbqt format were put in one folder named vina on local disk $C$. To run the docking simulation with autodock vina is run by using the command prom. 9 conformations will appear in the folder and the conformation used is the one that has the lower RMSD than $2 \AA$. To be able to see the results of docking, it can be visualized using the DS Visualizer application. Prior to that, convert files that have the PDBQT format into PDB using the Open Babel application so that it can be visualized using DS Visualizer. In the input section, enter the result of docking with pdbqt format, then change the output section to PDB, and do the conversion by pressing conver. The docking results can be visualized using DS Visualizer.

Effervescent Granule Formulation. Extract powder was obtained by putting thick extracts combination of tea leaves and soursop leaves into the oven at $45^{\circ} \mathrm{C}$ temperature for 72 hours.

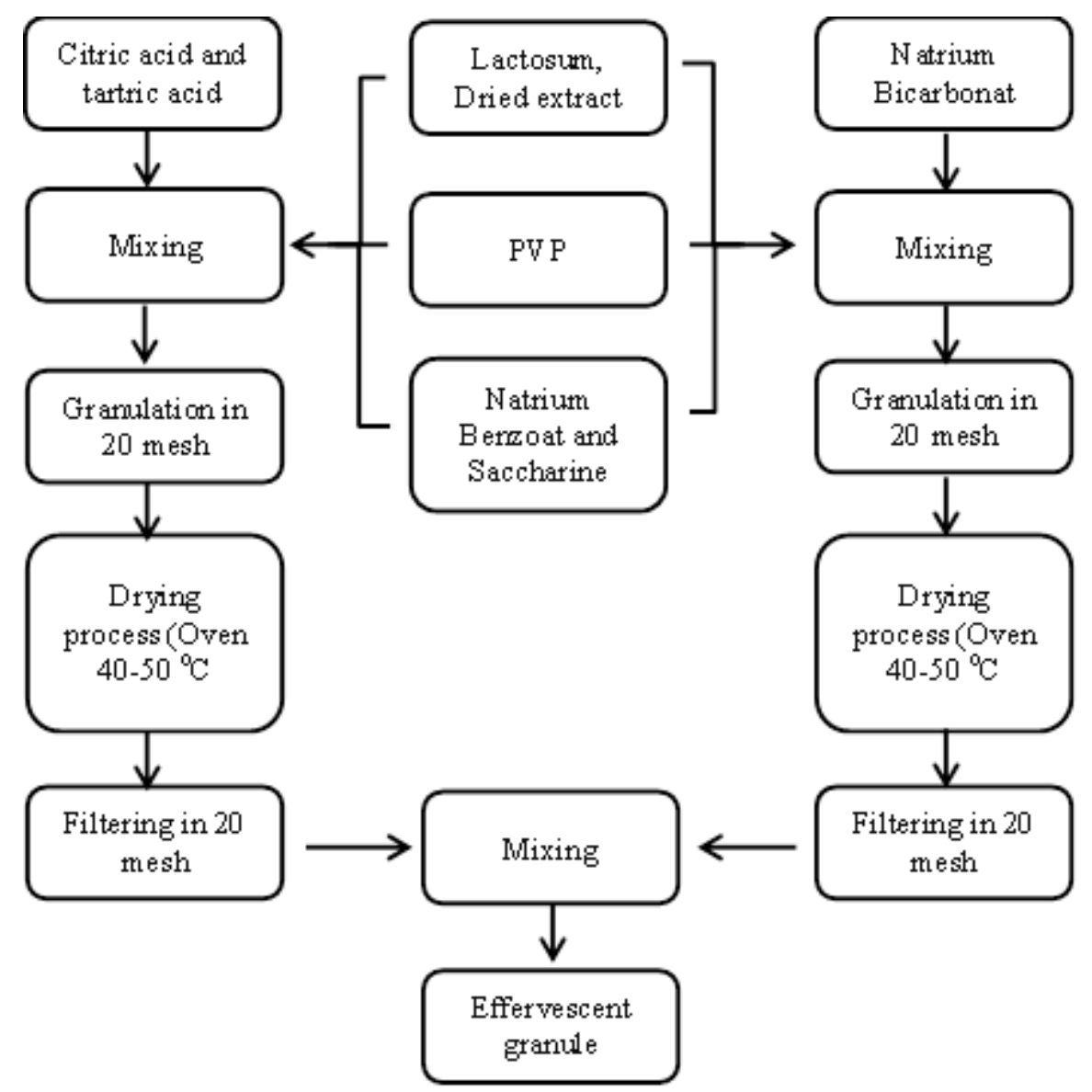

Figure 1. Flow Chart of Effervescent Granule Process 
Table 1. The Formula of Effervescent Granule

\begin{tabular}{cccccc}
\hline \multirow{2}{*}{ No } & \multirow{2}{*}{ Material } & \multicolumn{4}{c}{ Formulation (\%) } \\
\cline { 3 - 6 } & & F.1 & F.2 & F.3 & F.4 \\
\hline 1 & Extract Powder & 1,5 & 1,5 & 1,5 & 1,5 \\
2 & Citric Acid & 16,4 & 20,7 & 14 & 8 \\
3 & Tartic Acid & 11 & 14 & 23,5 & 26 \\
4 & Na Bicarbonate & 26 & 32 & 32,7 & 33 \\
5 & PVP & 1,4 & 1,4 & 1,4 & 1,4 \\
6 & Sodium & 1 & 1 & 1 & 1 \\
& Benzoate & & & & \\
7 & Saccharin & 0,5 & 0,5 & 0,5 & 0,5 \\
8 & Lactose & Ad & Ad & Ad & Ad \\
& & 100 & 100 & 100 & 100 \\
\hline
\end{tabular}

The test of physical Effervescent Granules includes organoleptic test, water content test, ph analysis, and granule dissolve test.

\section{RESULT}

Plant Identification. The identification result showed that samples used are tea leaves (Camellia sinensis) and soursop leaves (Annona muricata L.).

Extraction. The extraction method used in this study is maceration method. This method was chosen because the compounds in the Camellia sinensis' and Annona muricata L.'s simplicia can

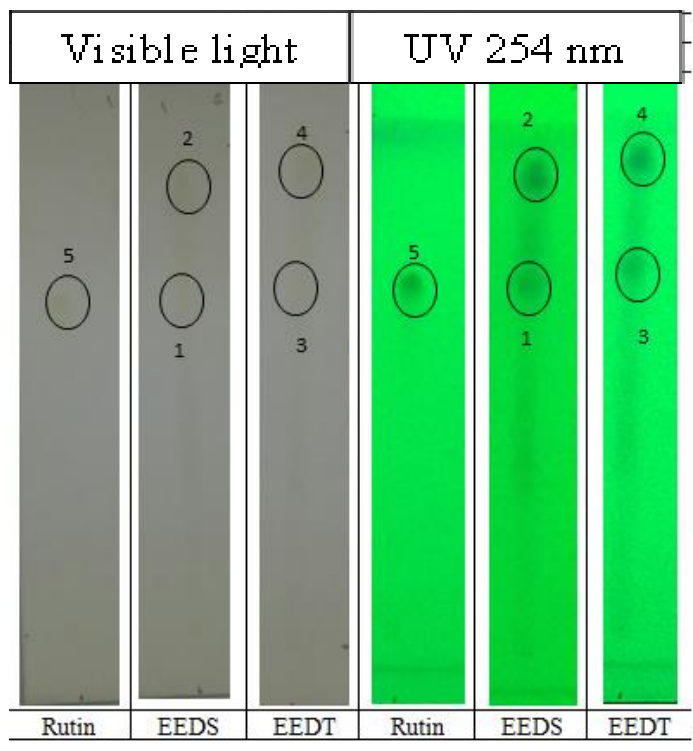

Figure 2. Plate TLC before ammoniac evaporation be damaged at high temperatures. The result of the maceration method was to obtain thick extract of Camellia sinensis weighing 27.3 grams and Annona muricata L. weighing 28.7 grams.

Thin-layer Chromatography. The stationary phase used was plate GF 254 silica gel, while the mobile phase used was $n$ - butanol : acetic acid : water (BAA). Based on these experiments, the BAA mobile phase with a ratio of $7: 2: 1$ shows the best separation result compared to other comparisons.

To detect flavonoids, colour testing was carried out with ammoniac compounds. Value Rf of each spot can be seen on Table 2.

Antioxidant Test with DPPH. The antioxidant test was carried out by spectrophotometric methods on several levels. Data on the average of absorbance reaction between DPPH and Vitamin C and DPPH in combination with EEDT and EEDS can be seen in Table 3.

To get the absorbance of the negative control, read the absorbance of DPPH solution. Based on the experimental results, it is obtained an average DPPH absorbance of 0.7023 . The results of calculation of Vitamin $C$ inhibition percentage can be seen in Table 4 while the inhibition percentage

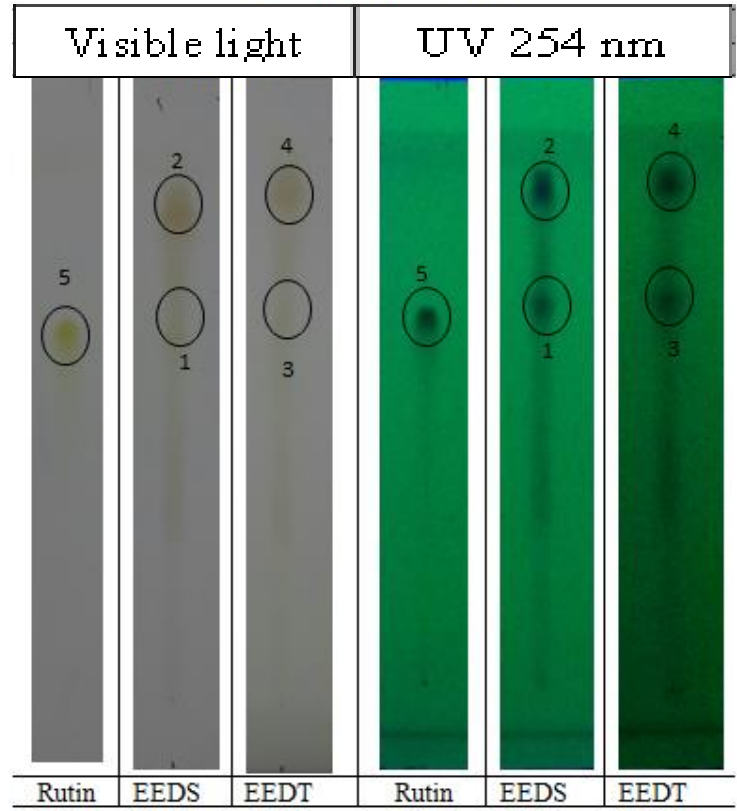

Figure 3. Plate KLT after ammoniac evaporation

Table 2. The Results of KLT from an Extract Combination of Tea Leaf and Soursop Leaf

\begin{tabular}{|c|c|c|c|c|c|}
\hline \multirow{2}{*}{$\begin{array}{c}\text { Spot } \\
\text { Number }\end{array}$} & \multirow{2}{*}{ Rf } & \multicolumn{2}{|c|}{ Colour Stain Before $\mathrm{NH}_{3}$ Evaporation } & \multicolumn{2}{|c|}{ Colour Stain After $\mathrm{NH}_{3}$ Evaporation } \\
\hline & & Colour & UV $254 \mathrm{~nm}$ & Colour & UV $254 \mathrm{~nm}$ \\
\hline 1 & 0,66 & Colourless & Damping & Yellow & Darker Damping \\
\hline 2 & 0,89 & Colourless & Damping & Amber Yellow & Darker Damping \\
\hline 3 & 0,68 & Colourless & Damping & Yellow & Darker Damping \\
\hline 4 & 0,91 & Colourless & Damping & Amber Yellow & Darker Damping \\
\hline 5 & 0,66 & Colourless & Damping & Yellow & Darker Damping \\
\hline
\end{tabular}


Table 3. Average Absorbance of Vitamin C

\begin{tabular}{cccc}
\hline No & $\begin{array}{c}\text { Concentration } \\
(\mu \mathrm{g} / \mathrm{mL})\end{array}$ & $\begin{array}{c}\text { Average } \\
\text { Absorbance }\end{array}$ & $\begin{array}{c}\text { Deviation } \\
\text { Standard }\end{array}$ \\
\hline 1 & 0,5 & 0,641 & 0,026 \\
2 & 1 & 0,638 & 0,006 \\
3 & 2 & 0,625 & 0,034 \\
4 & 5 & 0,557 & 0,013 \\
5 & 10 & 0,402 & 0,021 \\
6 & 20 & 0,189 & 0,063 \\
7 & 30 & 0,055 & 0,014 \\
\hline
\end{tabular}

of the data of EDT and EEDS combination can be seen in Table 5 .

Linear regression graph which shows the relationship between the concentration and the inhibition percentage of EEDT and EEDS combination as well as Vitamin C can be seen in Figure 4 and Figure 5 .

Upon obtaining a linear regression equation, IC 5o can be calculated. This value is obtained by converting value $y$ into 50 . The result count shows the value of IC ${ }_{50}$ Vitamin C of $14.20 \mathrm{pg} / \mathrm{mL}$, while the value for the extract combination is $26.9 \mathrm{mg} / \mathrm{mL}$.

Molecular Docking. The proteins tested in this study are HER-2 and ER-a receptors. The result of the molecular docking test of the two molecules is in

Table 4. Data Percentage of Vitamin C Inhibition

\begin{tabular}{cccc}
\hline No & $\begin{array}{c}\text { Concentration } \\
(\mu \mathrm{g} / \mathrm{mL})\end{array}$ & $\begin{array}{c}\text { Average } \\
\text { Absorbance }\end{array}$ & $\begin{array}{c}\text { Deviation } \\
\text { Standard }\end{array}$ \\
\hline 1 & 0,5 & 0,641 & 0,026 \\
2 & 1 & 0,638 & 0,006 \\
3 & 2 & 0,625 & 0,034 \\
4 & 5 & 0,557 & 0,013 \\
5 & 10 & 0,402 & 0,021 \\
6 & 20 & 0,189 & 0,063 \\
7 & 30 & 0,055 & 0,014 \\
\hline
\end{tabular}

Table 5. Data Percentage of EEDT and EEDS Combination

\begin{tabular}{cccc}
\hline No & $\begin{array}{c}\text { Concentration } \\
(\mu \mathrm{g} / \mathrm{mL})\end{array}$ & $\begin{array}{c}\text { Average } \\
\text { Absorbance }\end{array}$ & $\begin{array}{c}\text { Deviation } \\
\text { Standard }\end{array}$ \\
\hline 1 & 5 & 0,661 & 0,016 \\
2 & 7,5 & 0,598 & 0,022 \\
3 & 10 & 0,532 & 0,003 \\
4 & 15 & 0,488 & 0,017 \\
5 & 20 & 0,476 & 0,061 \\
6 & 30 & 0,298 & 0,018 \\
7 & 40 & 0,186 & 0,022 \\
\hline
\end{tabular}

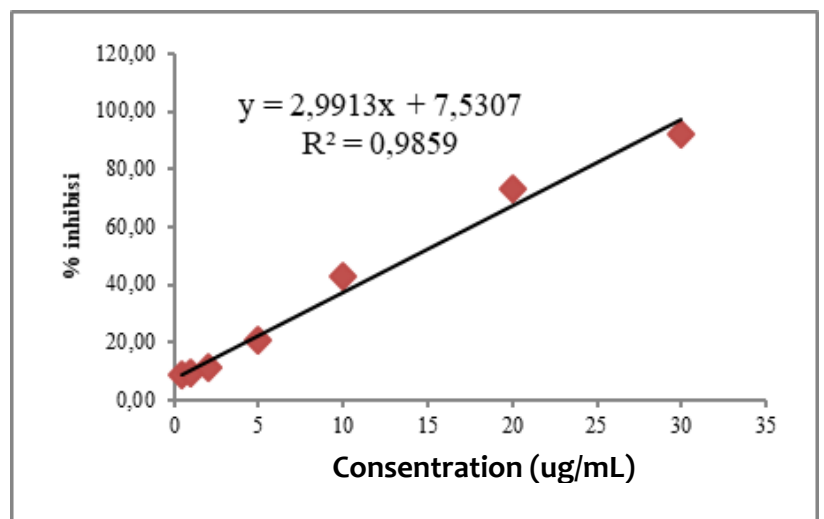

Figure 4. Linear Regression Graph of Vitamin C

the form of docking scores which means the free energy value needed by the ligand to interact with the protein target. RMSD value and docking scores between test compounds and the best valued HER2 receptor can be seen in Table 6 .

As for ER-a receptor, the RMSD and the bestvalued docking score can be seen in Table 7 .

Effervescent Granule Production. The observations upon the four formulas had less benefitted on flavour and the colour of the granules produced. The four formulas had a less sweet taste. However, it tasted fresh and less bitter when it is drunk. The aroma is quite good as the extract is not

Table 6. The Result of Molecular Docking Tests on the HER-2 Protein

\begin{tabular}{ccccc}
\hline No & Test Compound & Conformation & RMSD Value & Docking Score $(\mathrm{Kcal} / \mathrm{mol})$ \\
\hline 1 & Acetogenin & 4 & 1.621 & -6.3 \\
2 & Catechins & 6 & 1.857 & -6.7 \\
3 & Native Ligand (03Q) & 2 & 1.536 & -7.0 \\
4 & Doxorubicin & 2 & 1.619 & -7.0 \\
5 & 5-FU & 3 & 1.620 & -5.6 \\
\hline
\end{tabular}

Table 7. The Result of Molecular Docking Test on ER-a Receptor

\begin{tabular}{ccccc}
\hline No & Test Compound & Conformation & RMSD Value & Docking Score $(\mathrm{Kcal} / \mathbf{m o l})$ \\
\hline 1 & Acethogenin & 2 & 1.623 & -6.5 \\
2 & Catechins & 5 & 1.350 & -7.6 \\
3 & Native Ligand (6BOF) & 5 & 1.436 & -7.8 \\
4 & Doxorubicin & 4 & 1.412 & -6.0 \\
5 & 5-FU & 2 & 1.791 & -5.5 \\
\hline
\end{tabular}




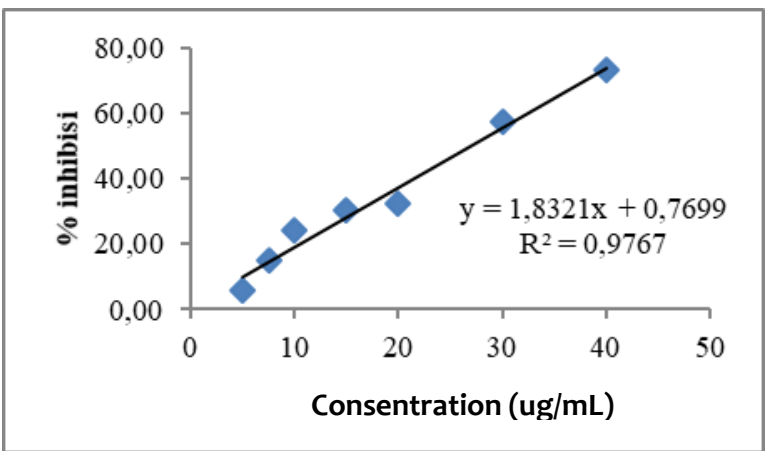

Figure 5. Linear Regression Graph of EEDT and EEDS Combination

Table 8. The Physical Test of Effervescent Granules on Each Formula

\begin{tabular}{|c|c|c|c|c|c|}
\hline \multirow[t]{2}{*}{ No } & \multirow[t]{2}{*}{ Information } & \multicolumn{4}{|c|}{ Formula } \\
\hline & & 1 & 2 & 3 & 4 \\
\hline 1 & $\begin{array}{c}\text { Water } \\
\text { Content (\%) }\end{array}$ & 1,34 & 1,73 & 1,53 & 1,07 \\
\hline 2 & $\mathrm{pH}$ & 5,98 & 5,81 & 5,80 & 6,18 \\
\hline 3 & $\begin{array}{l}\text { Dissolve Time } \\
\text { (seconds) }\end{array}$ & 95 & 66 & 97 & 45,5 \\
\hline
\end{tabular}

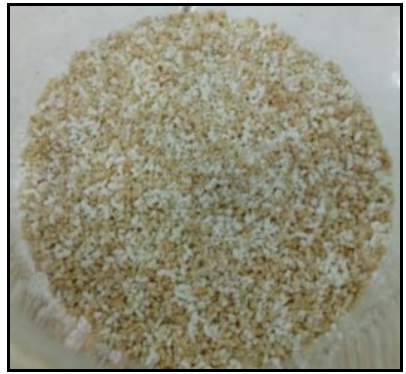

Figure 6. Organoleptic Test of Effervescent Granule

smelled. Furthermore, the colour of the granules is not identical as the dry brownish green extract is mixed only on the base component that the base component granule turns brownish while the acid component turns white. Granule Organoleptic examination can be seen in Figure 6 .

The physical test of Effervescent granule was conducted to find out that the granules produced had good quality. The results of the examination can be seen in Table 8 .

\section{DISCUSSION}

Ethanol extract of tea leaves and soursop leaves produces a yield value of $13.38 \%$ and $14.6 \%$, respectively. Preliminary tests to identify the content of flavonoids in EEDT (Tea Leaf Ethanol Extract) and EEDS (Soursop Leaf Ethanol Extract) were carried out by TLC method. The results of the separation of EEDT and EEDS compounds can use a solvent in combination with butanol, acetic acid, and water (BAA).

Based on the results of identification using TLC, EEDT sample with spot number 1 and 2 which reaches $\mathrm{Rf} 0.66$ and 0.89 as well as EEDS sample with spot number 3 and 4 which reaches $\mathrm{Rf} 0.68$ and 0.91 respectively are hypothesized to contain flavonoids. The four spots experienced a blue damping using UV $254 \mathrm{~nm}$ and they were colourless in visible light spectrum prior to ammoniac evaporation. Upon ammoniac evaporation on the visible spectrum, the dark yellow in spot 1 and 3 appeared indicating glycoside flavonoid. It aligned with the comparative $\mathrm{Rf}$ value used, which reaches 0.66 showed in spot 5 . The result refers to the previous studies showing that the $\mathrm{Rf}$ value ranges between 0.625 and 0.75 with the BAA mobile phase called quercetin. ${ }^{5}$ Quercetin, as well as catechins found in tea leaves and soursop leaves, are derivative flavonoids belonging to flavonol. ${ }^{6}$ Therefore, the routine use of the two as a comparison is appropriate to detect flavonoids. Furthermore, spots number 2 and 4 are not included in glycoside flavonoid compound as they have a different and higher Rf. It is presumeed that the compound is a type of genistein as it is such a less polar flavonoid. ${ }^{7}$ The $\mathrm{Rf}$ values of the two samples are somewhat identical. It indicates that the flavonoid compounds in the EEDT and EEDS samples have similar types of compounds.

One of action mechanism of chemo preventive agents is through a prevention process. It can be done by using antioxidant compounds that can neutralize the free radicals causing breast cancer. ${ }^{8}$ One of the compounds that function as antioxidants in natural material is the flavonoid compound. The flavonoid compounds found in the combination of EEDT and EEDS will donate protons, one of the free radicals namely element $\mathrm{H}$. It will interact with DPPH so that there is a bond that produces a more stable diphenyl picrihydrazine compound.

The greater the concentration of the comparative solution between vitamin $\mathrm{C}$ and the test solution is, the greater the ability to counteract free radicals will be. It can be seen by the decrease in absorbance value. The higher the concentration is, the more protons will be donated to DPPH free radicals. Based on the linear regression equation, the $\mathrm{IC}_{50}$ value of the combination of ethanol extract on Camellia sinensis and Annona muricata L. can be calculated, the value of which reaches $26.90 \mathrm{ug} / \mathrm{mL}$. According to Mardawati (2008), the result of the antioxidant test on the combination of ethanol extract of Camellia sinensis and Annona muricata L. indicates that the activity is categorized as a very powerful antioxidant. 9 
The result of molecular docking test on HER-2 indicates that the docking scores of acetogenin (-6.3 $\mathrm{kcal} / \mathrm{mol})$ and catechin $(-6.7 \mathrm{kcal} / \mathrm{mol})$ showed more negative compounds than its comparison of 5 -FU ($5.6 \mathrm{kcal} / \mathrm{mol})$. However, they showed more positive compounds compared with doxorubicin $(-7.0 \mathrm{kcal} /$ mol). It proves that the acetogenin and catechin compounds with HER-2 have better bond stability compared to 5-FU. However, they are less stable compared to doxorubicin and original ligand 03Q ($7.0 \mathrm{kcal} / \mathrm{mol}$ ).

In addition, the test result on the ER- $\alpha$ receptor indicated that the docking score of acetogenin ($6.5 \mathrm{kcal} / \mathrm{mol})$ and catechin $(-7.6 \mathrm{kcal} / \mathrm{mol})$ showed more negative compounds than its comparison of 5FU $(-5.5 \mathrm{kcal} / \mathrm{mol})$ and doxorubicin $(-6.0 \mathrm{kcal} / \mathrm{mol})$. It proves that the acetogenin and catechin compounds in the ER- $\alpha$ receptor have better bond stability compared to 5-FU and doxorubicin. However, they are more positive than the original ligand $6 \mathrm{BoF}$ $(-7,8 \mathrm{kcal} / \mathrm{mol})$. It can be interpreted that the energy needed by the two compounds to bind together with the ER-a receptor is less than that of 5-FU and doxorubicin, thus the bonds formed are more stable.

Based on the previous studies, catechins have been shown to have anticancer activity through the mechanism of anti-proliferation and induction of apoptosis cell through triggering protein p53. ${ }^{10}$ Likewise, the acetogenin compound has anticancer activity through inhibition of cell proliferation, induction program of cell apoptosis, and the increase of expression of $\mathrm{p} 53 .{ }^{11}$ As for the result of this study, catechin and acetogenin compounds have anticancer activity through an anti-proliferation mechanism with the inhibiting receptor targets of HER-2 and ER- $\alpha$, as well as increasing cell apoptosis program through the increase of Bad protein expression.

To increase the benefits of this research for the community, effervescent granule production was carried out. Powder materials basically have poor flowability, including extract powder as it is obtained from plants with high water content. Therefore, to improve the flowability, effervescent granules production is carried out by using the moist granulation technique. It is used because they have faster flowablity as well as identical size compared to powder. Furthermore, citric and tartric acid functioned in the effervescing process. The component of these acids were hydrolyzed in the water to produce acids that then reacted with sodium bicarbonate to produce carbon dioxide $\left(\mathrm{CO}_{2}\right)$ and water. The combination of citric and tartric acid is commonly carried out to avoid froth production difficulties because the use of single citric acid will produce a sticky mixture and that it is difficult to be produced into granules. On the other hand, the use of single tartaric acid will produce clot vulnerable granules.

The factor that can affect the acidity of the effervescent granule is the amount of $\mathrm{CO}_{2}$ production when effervescent interacts with water and another result of this reaction is carbonic acid. Carbonic acid will experience decomposition and produce $\mathrm{H}^{+}$ion in the solution and that it turns acidic. ${ }^{12}$ Equality of reactions that occur in effervescent production refers to the stoichiometric principle that one molecule of citric acid will react with three molecules of sodium bicarbonate, while tartric acid will react with two molecules of sodium bicarbonate. Thus, the reaction equation obtained as a comparison between sodium bicarbonate, citric, and tartric acid in sequence is 53: $28: 19 .{ }^{13}$

Based on the test results obtained, the water content of the four formulas did not meet the requirements. Factors that can affect water content are relative humidity, and the requirement of room's relative humidity $(\mathrm{RH})$ for the effervescent production which is $<25 \%$ with not more than $20^{\circ} \mathrm{C}$ temperature. ${ }^{14}$ Effervescent granules produced have different physical characteristics in each formula. The result of the physical effervescent granules test showed that formula 4 had the best result among other formulas with $\mathrm{pH} 6.18,1,07 \%$ water content, and 45.5 seconds of dissolve time.

\section{CONCLUSION}

The combination of ethanoic extracts of Camellia sinensis and Annona muricata L. is proved to contain flavonoid compounds. It has antioxidant activity based on DPPH technique with $I C_{50}$ values of $26.90 \mu \mathrm{g} / \mathrm{mL}$ which is classified as a strong value. Catechin and acetogenin compounds have a high bond affinity in inhibiting HER-2 and ER-a as evidenced by the docking score on HER-2 respectively namely $-6.7 \mathrm{kcal} / \mathrm{mol}$ and $-6.3 \mathrm{kcal} / \mathrm{mol}$. Moreover, the docking score on the receptor ER- $\alpha$ is $-7.6 \mathrm{kcal} /$ $\mathrm{mol}$ and $-6.5 \mathrm{kcal} / \mathrm{mol}$ respectively. The optimal effervescent granule formulation for the combination of ethanoic extract of Camellia sinensis and Annona muricata $\mathrm{L}$. is the fourth formula with the test results of $1.07 \%$ moisture content test, $\mathrm{pH}$ with a value of 6.18 , and dissolve time of 45.5 seconds.

\section{THANK-YOU NOTE}

We would like to express our gratitude to the Ministry of Research and Technology Republic of Indonesia for providing funds for conducting this research. 


\section{REFERENCE}

1. Kuzairi K, Yulianto T, Safitri L. Aplikasi Metode Adams Bashforth-Moulton (Abm) Pada Model Penyakit Kanker. J Mat MANTIK, 2016; 2: 14-21.

2. Boehm K, Borrelli F, Ernst E, Habacher G, Hung SK, Milazzo S, et al. 2009. Green Tea (Camellia sinensis) for the Prevention of Cancer, in: The Cochrane Collaboration (Ed.), Cochrane Database of Systematic Reviews. John Wiley \& Sons, Ltd, Chichester, UK. https://doi.org/10.1002/14651858.CD005004.p ub2

3. Liu J, Xing J, Fei Y. Green Tea (Camellia sinensis) and Cancer Prevention: A Systematic Review of Randomized Trials and Epidemiological Studies. Chin Med, 2008; 3: 12.

4. Adelina R, Febriyanti R, Aminah S, Pramono S. Isolasi Flavonoid Daun Murbei (Morus alba 1.) Serta uji Aktivitasnya sebagai Penurun Tekanan Darah Arteri pada Anjing Teranestesi. Maj Farm, 2013; 9: 235-242.

5. Suhendi A. Isolasi dan Identifikasi Flavonoid dari Daun Dewandaru (Eugenia uniflora L.). Pharmacon J Farm Indones, 2011; 12: 73-81.

6. Neldawati N. Analisis Nilai Absorbansi dalam Penentuan Kadar Flavonoid untuk Berbagai Jenis Daun Tanaman Obat. Pillar Phys. 2. 2013.

7. Markham KR. Cara Mengidentifikasi Flavonoid, diterjemahkan oleh Kosasih Padmawinata, 15, Penerbit ITB, Bandung. 1988.
8. Zhai S, Dai R, Friedman F. and Vestal R. Comparative Inhibition of Human Cytochromes P450 1A1 and 1A2 By Flavonoids. Drug Metabolism and Disposition, 1998; 26 (10): 989-9.

9. Mardawati E, Achyar CS, Marta MDH, et al. Kajian Aktivitas Antioksidan Ekstrak Kulit Manggis (Garcinia mangostana L) dalam Rangka Pemanfaatan Limbah Kulit Manggis di Kecamatan Puspahiang Kabupaten Tasikmalaya. Abstrak. 2008.

10. Nurani LH. Isolasi dan Uji Penangkapan Radikal Bebas DPPH oleh Isolat-1, Fraksi Etil Asetat, dan Ekstrak Etanol Akar Pasak Bumi (Eurycoma longifolia Jack). Pharmaciana 3, 2013.

11. Rachmawati E, Karyono S, Suyuti H. Efek Ekstrak Etanolik Daun Sirsak pada Proliferasi dan Apoptosis Sel HeLa yang Dimediasi oleh p53. J Kedokt Brawijaya, 2013; 27: 28-33.

12. Ansel HC. Pengantar Bentuk Sediaan Farmasi, diterjemahkan oleh Ibrahim, F., Edisi IV, 605-619, Jakarta, UI Press. 2005.

13. Syamsul ES, Supomo S. Formulation of Effervescent Powder of Water Extract of Bawang Tiwai (Eleuterine palmifolia) AS A HEALTHY DRINK. Maj Obat Tradis Tradit Med J, 2014; 19 (3): 113-117 19, 113-117.

14. Lee RE. Effervescent Tablets. CSC publishing, Tablets \& capsules. 2000. 